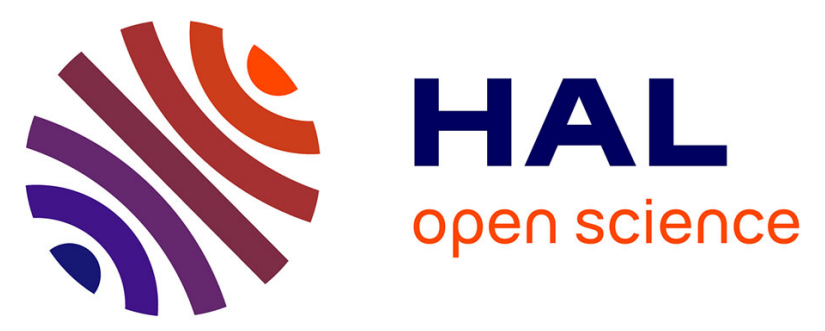

\title{
High-protein diet modifies colonic microbiota and luminal environment but not colonocyte metabolism in the rat model: the increased luminal bulk connection
}

Xinxin Liu, Jean-Marc Blouin, Arlette Santacruz, Annaig Lan, Mireille Andriamihaja, Sabina Wilkanowicz, Pierre-Henri Benetti, Daniel Tomé, Yolanda Sanz, Francois Blachier, et al.

\section{To cite this version:}

Xinxin Liu, Jean-Marc Blouin, Arlette Santacruz, Annaig Lan, Mireille Andriamihaja, et al.. Highprotein diet modifies colonic microbiota and luminal environment but not colonocyte metabolism in the rat model: the increased luminal bulk connection. AJP - Gastrointestinal and Liver Physiology, 2014, 307 (4), pp.G459 - G470. 10.1152/ajpgi.00400.2013 . hal-01173417

\author{
HAL Id: hal-01173417 \\ https://hal.science/hal-01173417
}

Submitted on 27 May 2020

HAL is a multi-disciplinary open access archive for the deposit and dissemination of scientific research documents, whether they are published or not. The documents may come from teaching and research institutions in France or abroad, or from public or private research centers.
L'archive ouverte pluridisciplinaire $\mathbf{H A L}$, est destinée au dépôt et à la diffusion de documents scientifiques de niveau recherche, publiés ou non, émanant des établissements d'enseignement et de recherche français ou étrangers, des laboratoires publics ou privés. 


\title{
High-protein diet modifies colonic microbiota and luminal environment but not colonocyte metabolism in the rat model: the increased luminal bulk
}

\section{connection}

\author{
Xinxin Liu, ${ }^{1}$ Jean-Marc Blouin, ${ }^{1}$ Arlette Santacruz, ${ }^{2}$ Annaïg Lan, ${ }^{1}$ Mireille Andriamihaja, ${ }^{1}$ \\ Sabina Wilkanowicz, ${ }^{2}$ Pierre-Henri Benetti, ${ }^{1}$ Daniel Tomé, ${ }^{1}$ Yolanda Sanz, ${ }^{2}$ François Blachier, ${ }^{1}$ \\ and Anne-Marie Davila ${ }^{1}$ \\ ${ }^{1}$ UMR914 Institut National de la Recherche Agronomique/AgroParisTech, Nutrition Physiology and Ingestive Behavior, Paris, \\ France; and ${ }^{2}$ Microbial Ecophysiology and Nutrition Research Group, Institute of Agrochemistry and Food Technology, \\ Spanish National Research Council, Valencia, Spain
}

Submitted 21 November 2013; accepted in final form 18 June 2014

Liu X, Blouin JM, Santacruz A, Lan A, Andriamihaja M, Wilkanowicz S, Benetti PH, Tomé D, Sanz Y, Blachier F, Davila AM. Highprotein diet modifies colonic microbiota and luminal environment but not colonocyte metabolism in the rat model: the increased luminal bulk connection. Am J Physiol Gastrointest Liver Physiol 307: G459-G470, 2014. First published June 26, 2014; doi:10.1152/ajpgi.00400.2013.-High-protein diets are used for body weight reduction, but consequences on the large intestine ecosystem are poorly known. Here, rats were fed for 15 days with either a normoproteic diet (NP, $14 \%$ protein) or a hyperproteichypoglucidic isocaloric diet (HP, 53\% protein). Cecum and colon were recovered for analysis. Short- and branched-chain fatty acids, as well as lactate, succinate, formate, and ethanol contents, were markedly increased in the colonic luminal contents of HP rats $(P<0.05$ or less) but to a lower extent in the cecal luminal content. This was associated with reduced concentrations of the Clostridium coccoides and $C$. leptum groups and Faecalibacterium prausnitzii in both the cecum and colon $(P<0.05$ or less). In addition, the microbiota diversity was found to be higher in the cecum of HP rats but was lower in the colon compared with NP rats. In HP rats, the colonic and cecal luminal content weights were markedly higher than in NP rats $(P<0.001)$, resulting in similar butyrate, acetate, and propionate concentrations. Accordingly, the expression of monocarboxylate transporter 1 and sodium monocarboxylate transporter 1 (which is increased by higher butyrate concentration) as well as the colonocyte capacity for butyrate oxidation were not modified by the HP diet, whereas the amount of butyrate in feces was increased $(P<0.01)$. It is concluded that an increased bulk in the large intestine content following HP diet consumption allows maintenance in the luminal butyrate concentration and thus its metabolism in colonocytes despite modified microbiota composition and increased substrate availability.

protein; microbiota; SCFA; transport; metabolism

HIGH-PROTEIN (HP) diets are commonly used for body weight loss $(36,38)$. In fact, such diets have been shown to increase satiety, to modify lipid metabolism, and to facilitate short- and middle-term weight reduction $(24,61,72)$. However, the consequences on gut microbiota composition, on microbial-derived metabolites in the large intestine luminal content, and on colonocyte epithelial cell metabolic capacities have been little studied.

Increasing protein intake induces an increase in the proportion of nitrogenous compounds, mainly protein, peptides, and

Address for reprint requests and other correspondence: A.-M. Davila, UMR914 INRA/AgroParisTech, Nutrition Physiology and Ingestive Behavior, Paris, France (e-mail: davila@agroparistech.fr). to a lesser extent amino acids, entering the large intestine (13, $23,25,51,64)$. They are subjected to luminal proteolysis and subsequent metabolism by the large number of microorganisms of the large intestine microbiota (about $10^{11}$ to $10^{12}$ viable bacteria/g content) (29) leading to the production of numerous amino acid-derived metabolites (53), including phenols, indoles, amines, sulfide, ammonia, and monocarboxylic acids. Monocarboxylic acids include short-chain fatty acids (SCFA), branched-chain fatty acids (BCFA) and several other organic acids. In contrast to SCFA, which are produced from indigestible carbohydrates, other metabolites such as BCFA are produced by the microbiota exclusively from amino acids (55). Changes in diet composition may affect the composition and metabolic activities of the microbiota that adapts to the new colonic luminal environment and substrate availability. Phyla composing the microbiota are known to be quite stable over their lifetime, but the dietary composition influences the repartition of species and functional groups (69). This has been particularly documented for carbohydrates, fibers, and more recently for fat-rich diets $(35,48)$. In contrast, few studies have addressed the influence of protein-rich diet on the composition and activity of the gut microbiota (8).

The colonic luminal environment may influence colonic epithelial cell metabolic capacities. SCFA and other monocarboxylic acids like lactate are absorbed from the lumen to the colonocyte cytosol by transport processes involving the monocarboxylate transporter 1 (MCT1), the protein CD147 (that participates to the apical expression of MCT1), and the sodium monocarboxylate transporter 1 (SMCT1) $(11,57)$. The absorbed components are partly metabolized mainly through oxidation pathways and used as energy substrates by colonic epithelial cells, with the unmetabolized fractions being recovered in the portal blood plasma and used by other tissues (3, 45). These bacterial metabolites, and particularly butyrate, are involved in numerous processes regarding colonocytes metabolism and physiology, including expression of MCT1 $(10,16)$, sodium-dependent fluid absorption (6), cell proliferation (20), histone acetylation, and gene expression (1, 20). Indeed, butyrate is considered as the preferential oxidative substrate for colonocytes $(19,58)$. In contrast to butyrate and propionate, which are mainly metabolized by the intestinal mucosa and liver, acetate is recovered in significant amount in the systemic blood (45).

The present study aims to evaluate the influence of HP diet on the composition of the intestinal microbiota, on the com- 
Table 1. Composition of the experimental diets

\begin{tabular}{lcc}
\hline \hline & NP & HP \\
\hline Ingredients, g/kg & & \\
Whole milk proteins & 140 & 530 \\
Sucrose & 100 & 45.7 \\
Corn starch & 622.4 & 287 \\
Mineral mixture AIN 93-M & 35 & 35 \\
Vitamin mixture AIN 93-V & 10 & 10 \\
Soybean oil & 40 & 40 \\
Cellulose & 50 & 50 \\
Choline & 2.3 & 2.3 \\
Energy, kJ/g & 14.6 & 14.6 \\
\hline
\end{tabular}

NP, normoproteic diet; HP, high-protein diet."Data from Ref. 56.

position of SCFA, BCFA, and other organic acids in cecal and colonic contents, and on putative modifications of energy metabolism in colonic epithelial cells. The central role of butyrate on colonocyte physiology suggests the necessity of an exquisite regulation of butyrate availability for both energy production and gene expression in these cells $(1,2,34,62,65)$. Thus, we evaluated if the modifications of the gut ecosystem following HP diet ingestion are associated with metabolic changes toward butyrate (and other energy substrates) in isolated colonic epithelial cells or if, conversely, metabolic homeostasis is maintained in these cells after such a dietary modification.

\section{MATERIALS AND METHODS}

Animals, diets, and colonocyte isolation. Wistar male rats (150 g) were acclimatized for 6 days to receive a standard rodent diet containing $16 \%$ (wt/wt) protein. Then they were randomly allocated to either normoproteic diet (NP) diet containing 14\% (wt/wt) protein or $\mathrm{HP}$ isocaloric diet (by decreasing digestible carbohydrates) containing $53 \%$ (wt/wt) protein (Table 1). After 15 days of experimental diet, animals were anesthetized with pentobarbital sodium $(40 \mathrm{mg} / \mathrm{kg}$ body $\mathrm{wt}$ ), and total cecal and colonic luminal contents were collected by expulsion. Luminal contents $(0.2 \mathrm{~g})$ were taken after homogenization for bacterial DNA extraction, and the remaining was frozen in liquid nitrogen and kept at $-80^{\circ} \mathrm{C}$ for subsequent analysis. The whole colon was used for colonocyte isolation using the perfusion method with EDTA as described (52). The present protocol received written agreement from the local animal ethical committee (COMETHEA at Jouy-en-Josas, France, Nos. 11/042 and 12/090).

Bacterial DNA extraction. Bacterial DNA extraction of fresh cecal and colonic luminal contents was performed with a QIAamp DNA Stool Mini kit (Qiagen). The DNA concentration and purity were measured with Nanodrop. The DNA integrity was confirmed by electrophoresis on agarose gel with Gelred staining. Extracted bacterial DNA was normalized to $30 \mathrm{ng} / \mu \mathrm{l}$ for subsequent real-time $\mathrm{qPCR}$ assay.

Analysis of microbiota composition by real-time $q P C R$. The main bacterial groups of the intestinal microbiota were quantified by realtime qPCR using specific primers (Table 2) and SYBR Green I Master mix (Roche Diagnostics) in a LightCycler 480 instrument (Roche Diagnostics) as previously described (59). The bacterial groups included total bacteria, Bifidobacterium, Lactobacillus group, Bacteroides fragilis group, Clostridium coccoides group, C. leptum group, Enterobacteriaceae, Desulfovibrio spp., and Faecalibacterium prausnitzii. Standard curves of each bacterial group were generated from serial dilutions of a known copy number of the target gene cloned into a plasmid vector. For each reference strain, the 16S rRNA gene was cloned into a pGEM-T Easy Vector System (Promega). An Escherichia coli strain was transformed with the recombinant plasmid, and plasmid DNA was extracted from $E$. coli by the miniprep method.

Denaturing gradient gel electrophoresis. PCR amplifications with universal primers and denaturing gradient gel electrophoresis (DGGE) analysis were performed as described (60). Renyi's entropy (diversity profile) was used to explore differences in bacterial species detected by DGGE and DNA sequencing between the different diets. The formula of Renyi's entropy is:

$$
H \alpha=\frac{\operatorname{In}\left(\sum_{i=1}^{S} P_{i}^{\alpha}\right)}{1-\alpha}
$$

where $S$ is the number of species in the sample and $P_{i}$ is the proportion of the species $i$ in the sample. Diversity profiles are calculated by changing the value of $\alpha$ from zero to infinity. Their graphical display provides diversity ordering of samples. A sample profile always above the profile of another sample indicates a higher diversity. The shape of the profile is an indication of evenness. The flatter the curve is, the higher the evenness is. Renyi's entropy also provides information on

Table 2. Primers used for bacterial DNA amplification for microbiota composition analysis

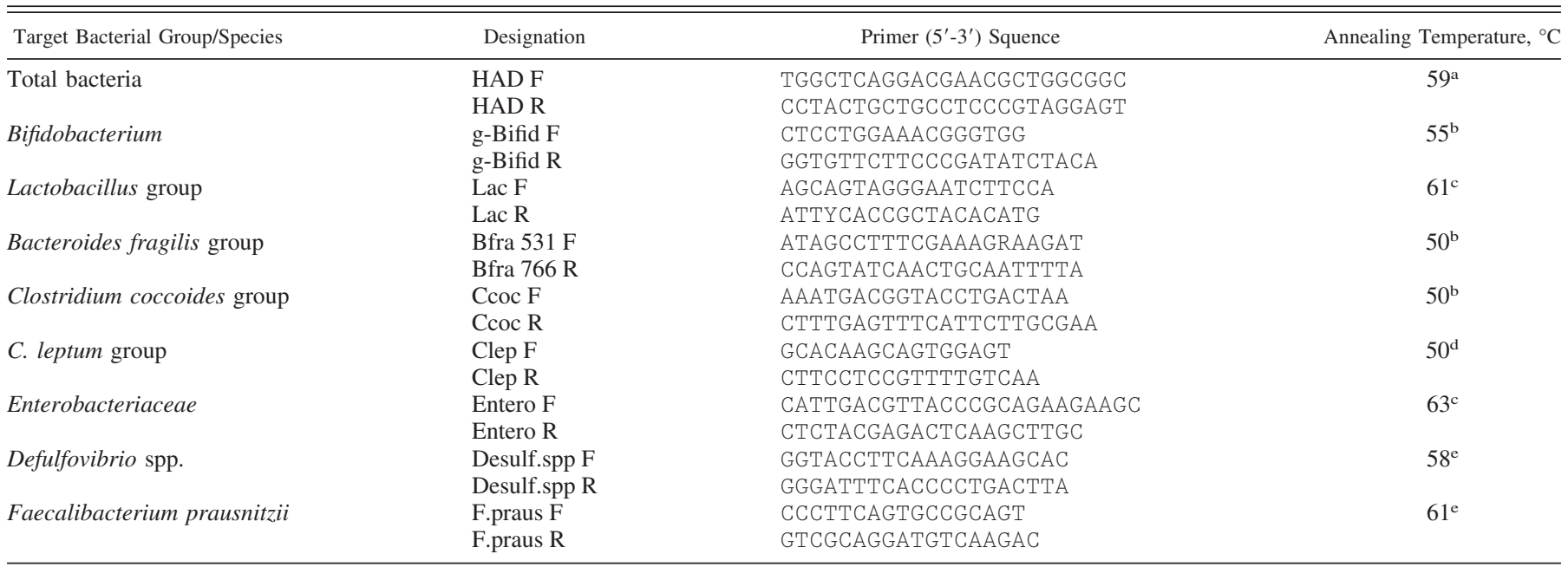

F, forward primer; R, reverse primer. The program of PCR was as follows: initial denaturation at $95^{\circ} \mathrm{C}$ for 5 min; 40 cycles of denaturation at $95^{\circ} \mathrm{C}$ for 10 $\mathrm{s}$, annealing at primer-specific temperature for $10 \mathrm{~s}$ and extension at $72^{\circ} \mathrm{C}$ for $30 \mathrm{~s}$; and melting curve at $95^{\circ} \mathrm{C}$ for $5 \mathrm{~s}, 65^{\circ} \mathrm{C}$ for $1 \mathrm{~min}$, and $98^{\circ} \mathrm{C}$ continuous followed by cooling to $40^{\circ} \mathrm{C}$. Data from Refs. 70 (a), 49 (b), 12 (c), 50 (d), and 47 (e). 
three further diversity index values: species richness for $\alpha=0$, Shannon index for $\alpha=1$, and Simpson index for $\alpha=2$. (68).

Analysis of SCFA, BCFA, and other organic acids in luminal contents and in feces. Cecal and colonic contents recovered at death were immediately weighted. The feces were recovered during the 3 days before death. All of the organic acids and ethanol were extracted from contents and feces by vigorous homogenization with diluted ultrapure water followed by centrifugation $\left(14,000 \mathrm{~g}, 15 \mathrm{~min}\right.$ at $\left.4^{\circ} \mathrm{C}\right)$. The SCFA and BCFA in the supernatants were then derivatized by esterification and analyzed with a gas chromatograph equipped with a capillary column (30 m, $0.32 \mathrm{~mm}$ ID; RestekRtx 502.2) and fitted with a flame ionization detector using a modification of the method of Kristensen et al. (39). The amounts of SCFA and BCFA were determined by external standards with reference to internal standards. Formate, L- and D-lactate, succinate, and ethanol were measured in cecal and colonic samples using the Megazyme biochemical assay kits (Megazyme) according to the manufacturer's instructions. To calculate the percentages of ingested energy lost in feces as SCFA, we used the corresponding values as defined by Livesey and Elia (42) with acetate representing $3.48 \mathrm{kcal} / \mathrm{g}$, propionate representing $4.93 \mathrm{kcal} / \mathrm{g}$, and butyrate representing $5.92 \mathrm{kcal} / \mathrm{g}$.

Metabolic assays in isolated colonocytes. Isolated colonocytes were resuspended in Krebs-Henseleit bicarbonate-buffered medium (pH 7.4), enriched with $10 \mathrm{mg} / \mathrm{ml} \mathrm{BSA}$. The incubation medium was equilibrated against a mixture of $\mathrm{O}_{2}-\mathrm{CO}_{2}(19: 1, \mathrm{vol} / \mathrm{vol})$. D-Glucose, L-glutamine, n-butyrate, and L-lactate oxidation by isolated colonocytes was carried out at $37^{\circ} \mathrm{C}$ in the incubation medium containing 5 $\mathrm{mM}$ D-glucose containing tracer amounts of $\mathrm{D}-\left[1-{ }^{14} \mathrm{C}\right]$ glucose, $1 \mathrm{mM}$ L-glutamine containing tracer amount of L- $\left[\mathrm{U}-{ }^{14} \mathrm{C}\right]$ glutamine, $2 \mathrm{mM}$ sodium butyrate containing tracer amount of $\mathrm{n}-\left[1-{ }^{14} \mathrm{C}\right]$ butyrate (sodium salt), or $2 \mathrm{mM}$ L-lactate containing tracer amount of L-[U$\left.{ }^{14} \mathrm{C}\right]$ lactate. The incubation was stopped with perchloric acid (3\% final concentration), and radioactive $\mathrm{CO}_{2}$ was measured by liquid scintillation after trapping in methylbenzethonium hydroxide. Lactate production by colonocytes from $5 \mathrm{mM}$ D-glucose was determined in the incubation medium using a colorimetric system as described by the manufacturer's instructions (Biovision/Clinisciences).

Gene expression analysis in colonocytes. Total RNA was extracted from isolated colonocytes using Trizol extraction derived from the method of Chomczynski and Sacchi (14). A subsequent step of DNase and purification was done with the RNeasy Mini Kit and DNase I (Qiagen). Next, sample quality was controlled by the 260 -to-280 $\mathrm{nm}$ absorption ratio measured with Nanodrop (between 1.8 and 2.0) and checked on $1 \%$ agarose gel. For real-time RT-PCR analyses, $1 \mu \mathrm{g}$ total RNA was first reverse transcribed using the High Capacity cDNA Archive kit (Applied Biosystems). Reverse-transcribed RNA (5 ng of cDNA) were amplified on a thermal cycler (ABI prism 7900 HT; Applied Biosystems) using the SYBR green fluorescence method and specific primers (Table 3). Results were analyzed with the SDS 2.1 real-time detection system software. Quantification of RNA was carried out by comparison of the number of cycles required to reach reference and target threshold values $\left(\delta-\delta C_{t}\right.$ method) and was normalized using Ribosomal Protein L13a (Rpl13a) mRNA.

Western blot analysis of MCT1 and SMCT1 in colonocytes. The cell surface expression of MCT1 and SMCT1 was achieved using the cell surface protein isolation kit (Pierce Biotechnology). Briefly, surface proteins of isolated colonocytes were biotinylated with the membrane-impermeant reagent Sulfo-NHS-LC-Biotin during $30 \mathrm{~min}$ at $4^{\circ} \mathrm{C}$. The reaction was quenched, and, after a washing step, membrane proteins were solubilized by incubation in Triton X-100containing buffer. Biotinylated proteins were bound to ImmunoPure immobilized streptavidin (Pierce), washed three times, and then dissolved in $62.5 \mathrm{mM}$ Tris. $\mathrm{HCl}$, pH 6.8, with $50 \mathrm{mM}$ DTT.

Equal amounts of protein were loaded on 4-12\% NuPAGENovexBisTris gel (Invitrogen) and run using $1 \times$ NuPage MES buffer. The XCellSureLock Mini Cell (Invitrogen) was used for electrophoresis. Protein was then transferred to Hybond ECL membranes that were blocked for $2 \mathrm{~h}$ at room temperature using $1 \times$ Tris-buffered saline (TBS, pH 7.5), $0.05 \%$ Tween 20, and 5\% (wt/vol) nonfat dry milk and incubated overnight $\left(4^{\circ} \mathrm{C}\right)$ with polyclonal antisera raised against rat MCT1 (1:5,000; Millipore) or rat SMCT1 (1:500; Santa Cruz Bio-

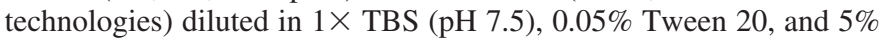
(wt/vol) BSA. Nitrocellulose membranes were then washed with $1 \times$ TBS and $0.05 \%$ Tween 20 and incubated for $1 \mathrm{~h}$ at room temperature with horseradish peroxidase-linked secondary antibody anti-chicken IgG to reveal MCT1 or anti-goat to reveal SMCT1. Bound antibody was visualized using the ECL (Enhanced ChemiLuminescence) system according to the manufacturer's instructions (Pierce Biotechnology).

Immunofluorescence analysis of MCT1 and SMCT1 in colon. For immunohistochemical studies, segments of colon were immediately fixed in $4 \%$ paraformaldehyde and embedded in paraffin. Fourmicrometer tissue sections were subjected to deparaffinization and washed with TBS plus $0.025 \%$ Triton X-100. Nonspecific binding sites were then blocked for $2 \mathrm{~h}$ at room temperature with TBS plus $1 \%$ BSA and $10 \%$ normal serum. Next, the sections were incubated with MCT1 antibody (1:500) and SMCT1 antibody (1:100) diluted in TBS plus $1 \% \mathrm{BSA}$ in a humidified chamber at $4^{\circ} \mathrm{C}$ overnight. Subsequently, the sections were washed two times in TBS plus $0.025 \%$ Triton X-100 and exposed for $1 \mathrm{~h}$ to AlexaFluor 488-conjugated secondary antibodies diluted in TBS plus $1 \%$ BSA. After being washed in TBS, sections were mounted using Vectashield mounting medium (Vector Laboratories).

Statistical analysis. The results are expressed as mean values $\pm \mathrm{SE}$. Statistical analyses were performed by using SAS 9.1 (SAS Institute, Cary, NC). Rats' body weight and food intake analysis were performed using the mixed model for repeated-measure analysis, and the differences between NP and HP groups at each time point are revealed by Tukey's post hoc test. The Welch's $t$-test was used to compare two groups. The difference in microbiota composition was analyzed by Mann-Whitney-Wilcoxon test. The prevalence of bacterial species identified by PCR-DGGE was analyzed by Fisher's test. Differences with $P$ values $<0.05$ were considered as statistically significant.

\section{RESULTS}

Body weight gain and weight of the cecal and colonic contents. Differences in rat weight gain of the HP group compared with the NP group were significantly more marked in the second half of diet intervention (Fig. 1A), whereas the differences in their daily food intake were more marked in the

Table 3. Primers used for gene expression analysis in isolated rat colonocytes

\begin{tabular}{clll}
\hline \hline RNA & Accession No. & Forward Primer (5'-3') Sequence & Reverse Primer (5'-3') Sequence \\
\hline Mct1 & NM 012716.2 & GCAACGACCAGTGAAGTGT & AAGCCCAAGACCTCCAAT \\
Smct 1 & NM 001191987.1 & CTGGGCTTGTTTTCTTTGG & CGTTGTGCGTGCTGTTAC \\
Rpll13a & NM 001109882.1 & AGTGAGGGAGAGTTGTGAAG & TCAGTGCCGTTGGAGATAG \\
\hline
\end{tabular}

Mct1, monocarboxylate transporter 1; Smct1, sodium monocarboxylate transporter 1 . The program of PCR was as follows: $95^{\circ} \mathrm{C}$ for 10 min, followed by 40 cycles of $15 \mathrm{~s}$ at $95^{\circ} \mathrm{C}, 1 \mathrm{~min}$ at $60^{\circ} \mathrm{C}$. 


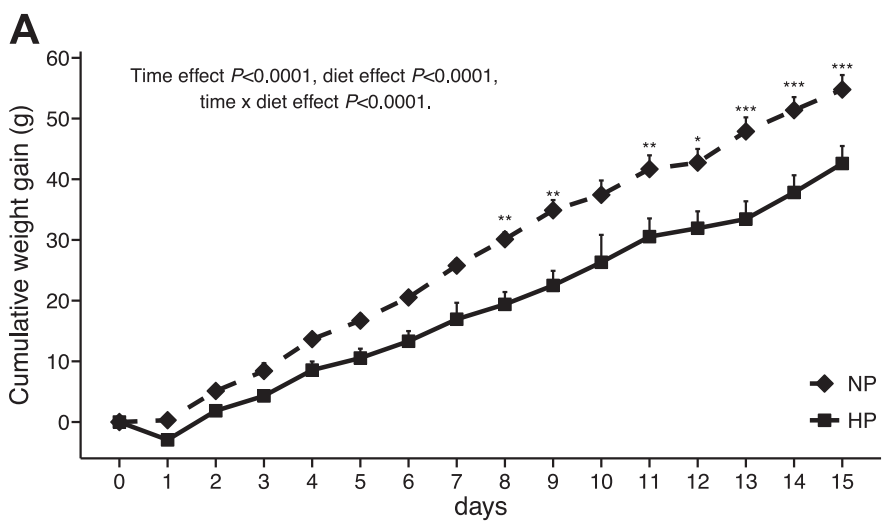

B
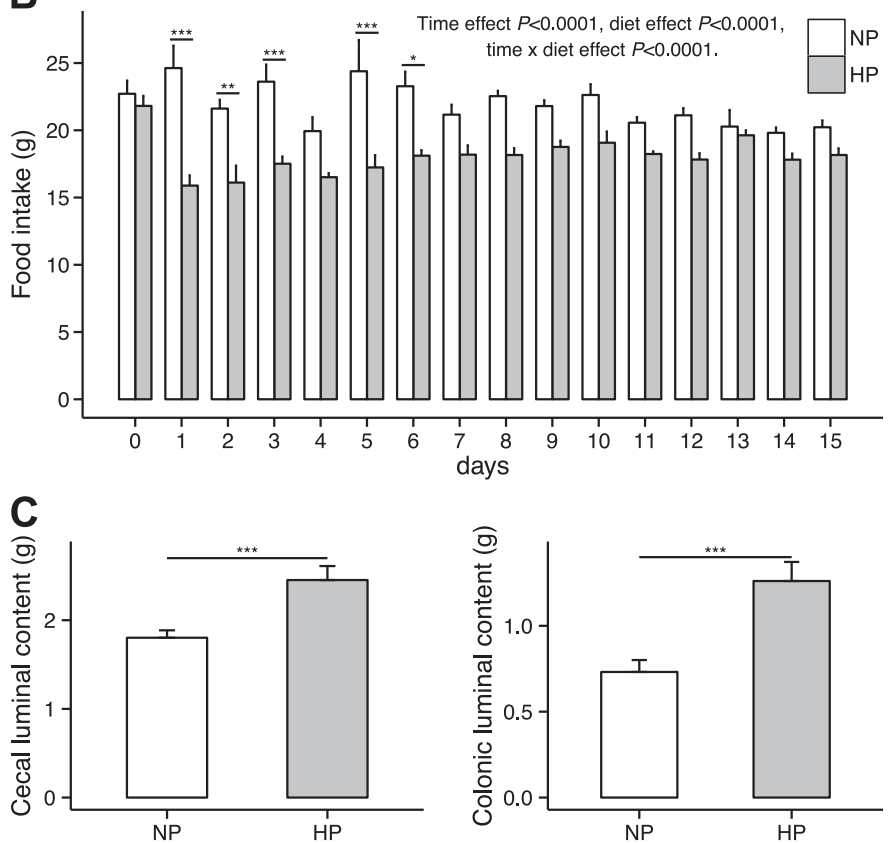

Fig. 1. Characteristics of animals after normoproteic diet (NP)/hyperproteichypoglucidic isocaloric diet (HP) feeding for 15 days. Cumulative body weight gain $(A)$, food intake $(B)$, and weight of the cecal and colonic luminal contents $(C)$ recovered from rats. The results were obtained from 8 animals in each group and are expressed as means $\pm \mathrm{SE}$. $* P<0.05, * * P<0.01$, and $* * * P<0.001$.

first half (Fig. 1B). The weight of the cecal and colonic luminal contents was increased by 136 and $172 \%$, respectively, in HP animals compared with NP animals (Fig. 1, C and D).

Microbiota composition, biodiversity, and species prevalence. The results of the effects of the HP diet on gut microbiota composition determined by real-time PCR are shown in Table 4. The total bacterial concentration was slightly but significantly decreased (1.3-fold) in the colon of HP animals compared with NP animals. However, total bacterial concentrations detected in the cecal luminal contents were similar between NP and HP animals. C. coccoides group gene copy numbers had a 4.3- and 1.6-fold decline in cecum and colon of HP animals, respectively, compared with NP diet. A marked decrease of $C$. leptum group gene copy numbers was also detected in cecum and colon of the HP group with, respectively, 2.2- and 3.4-fold change compared with NP animals. Finally $F$. prausnitzii gene copy numbers were dramatically decreased in both cecum (2.3-fold) and colon (4.6-fold) after HP diet. The concentrations of Bifidobacterium, Lactobacillus group, B. frafilis group, Enterobacteriaceae, and Desulfovibrio spp. did not differ significantly between the HP and NP groups.

Bacterial community fingerprint in the cecal and colonic luminal contents was analyzed by PCR-DGGE. The DNA banding pattern obtained was used to determine the species diversity with the Renyi's entropy (Fig. 2). HP diet consumption compared with NP diet increased diversity, richness, and evenness in cecum. By contrast, HP diet consumption decreased diversity and richness in colon but had no effect on evenness. Whatever the diet, gut microbiota displayed greater diversity and richness in cecal contents than in colonic contents. With NP diet, evenness was lower in cecum than in colon. With HP diet, evenness became similar in cecum and colon.

The assignment of PCR-DGGE bands to bacterial species (Table 5) shows an increased number of different bacterial species identified by PCR-DGGE ( $>90 \%$ identity in the GenBank using the BLAST algorithm) in cecal content than in colonic content. Several of these bacterial species had significantly higher or lower prevalence with the HP diet depending on the bacterial species. Clostridium sp. had significantly lower prevalence $(0 \%)$ in both colonic and cecal contents with the HP diet than with the NP diet. These results are consistent with that obtained by the absolute quantification by real-time PCR, where two important groups of Clostridium were decreased. $B$. vulgatus was also identified in both cecal and colonic contents, with an increased prevalence after the HP diet only in cecal content. The prevalences of $B$. dorei and Fusobacterium sp. were different according to the diet and opposite depending on the large intestine segment considered. Indeed, their prevalence increased significantly in cecal content, whereas in colonic content their prevalence decreased. E. coli was identified only in cecal content, where its prevalence was significantly lower in HP- than in NP-fed animals.

Organic acids in cecal and colonic luminal contents. The total quantity of organic acids in the luminal contents mainly follows the mass of the luminal contents. When calculating their quantity in the whole cecal contents, the total amount of acetate, isobutyrate, isovalerate, formate, and succinate was significantly higher, whereas the total amount of L-lactate, D-lactate, and ethanol was not significantly different in the HP group compared with the NP group (Fig. 3, $A$ and $B$, and Table 6). For the quantity in the whole colonic content, the total amounts of acetate, propionate, butyrate, valerate, isobutyrate, isovalerate, L-lactate, D-lactate, succinate, and ethanol were significantly higher except formate in the HP group compared with the NP group (Fig. 3, $C$ and D, and Table 6). However, when these results were expressed as concentrations in cecal and colonic luminal contents, the concentrations of SCFA were not significantly different after HP diet compared with NP diet (Table 7).

In the feces, the total quantity in acetate, propionate, and butyrate recovered for the three last days was 1.9-, 2.6-, and 2.1-fold higher for HP animals compared with NP animals (Fig. $3 E$ ). Figure $3 F$ shows the relative amounts of energy lost as SCFA in feces expressed as percentages of energy intake.

Energy substrate metabolism and expression of monocarboxylic and sodium transporters in isolated colonocytes. As indicated in Fig. 4A, the oxidation of butyrate was not signif- 
Table 4. Microbiota composition in the cecal and colonic luminal contents recovered from rats after NP/HP feeding for 15 days determined by real-time qPCR

\begin{tabular}{|c|c|c|c|c|c|}
\hline Bacterial Group & \multicolumn{2}{|c|}{ NP } & \multicolumn{2}{|c|}{ HP } & $P$ Value \\
\hline \multicolumn{6}{|l|}{ Cecal luminal contents } \\
\hline Bifidobacterium & 6.6 & $5.6-7.9$ & 7.0 & $6.6-7.5$ & 0.307 \\
\hline Lactobacillus group & 8.5 & $8.0-8.9$ & 8.3 & $7.9-8.8$ & 0.495 \\
\hline Bacteroides fragilis group & 11.1 & $10.9-11.2$ & 11.2 & $11.2-11.3$ & 0.124 \\
\hline C. coccoides group & 10.7 & $10.6-10.8$ & 9.2 & $7.7-10.2$ & $0.028 *$ \\
\hline F. prausnitzii & 8.5 & $8.3-8.9$ & 7.7 & $7.4-8.0$ & $<0.001^{*}$ \\
\hline Enterobacteriaceae & 10.6 & $10.4-10.7$ & 10.6 & $10.2-10.9$ & 0.909 \\
\hline \multicolumn{6}{|l|}{ Colonic luminal contents } \\
\hline Total bacteria & 12.4 & $12.4-12.5$ & 12.2 & $12.1-12.3$ & $0.002 *$ \\
\hline Bifidobacterium & 7.4 & $7.1-7.6$ & 7.0 & $6.9-7.2$ & 0.052 \\
\hline Lactobacillus group & 9.2 & $8.7-9.5$ & 8.6 & $8.1-9.2$ & 0.218 \\
\hline B. fragilis group & 11.6 & $11.3-11.8$ & 11.4 & $11.1-11.6$ & 0.248 \\
\hline Enterobacteriaceae & 10.7 & $10.5-10.9$ & 10.6 & $10.2-10.8$ & 0.436 \\
\hline
\end{tabular}

IQR, interquartile range. Results are expressed as log of gene copy numbers of the different bacterial groups/species per gram of wet luminal content and were obtained from 8 animals in each group. * Statistically significant difference.

icantly different in colonocytes isolated from NP and HP animals and neither was the oxidation of the substrates originating from blood, i.e., L-glutamine and D-glucose. Furthermore, the production of L-lactate from D-glucose in isolated

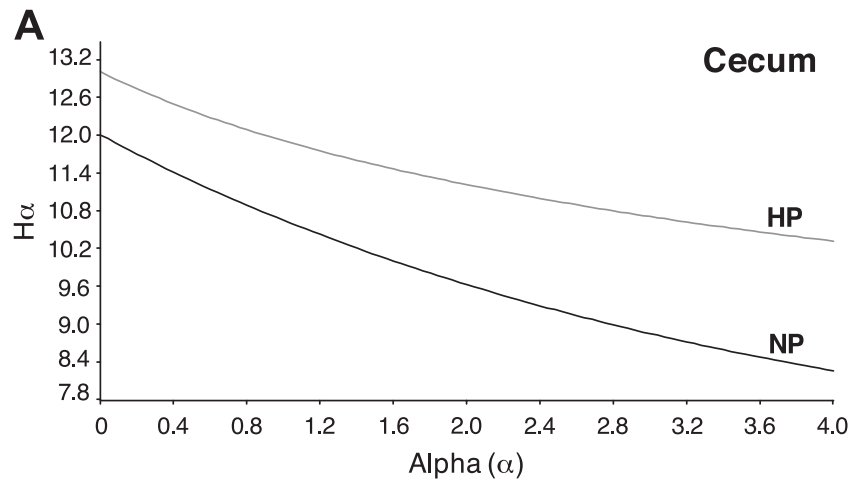

B

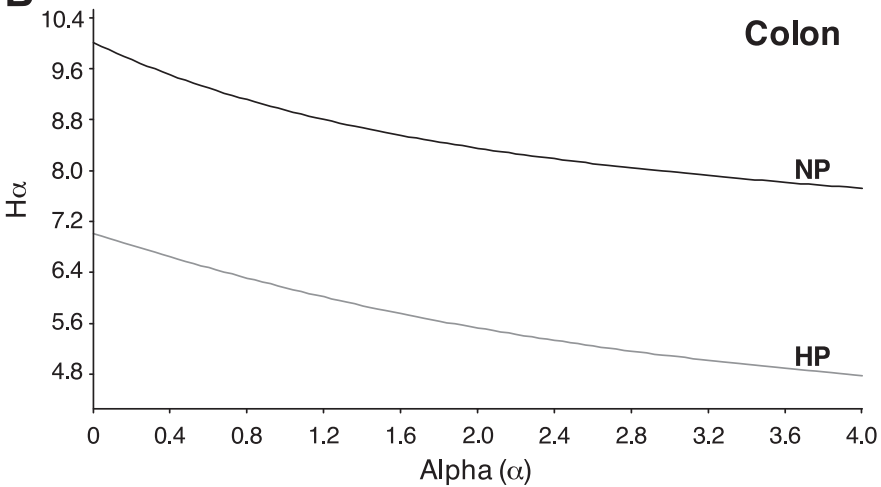

Fig. 2. Renyi's diversity profiles of microbiota in luminal content of rats after NP/HP feeding for 15 days. A: diversity profiles in the cecal luminal contents; $B$ : diversity profiles in the colonic luminal contents. Results were obtained from 8 animals in each group. colonocytes was similar in NP and HP animals $(241 \pm 27$ and $232 \pm 42 \mathrm{nmol} \cdot \mathrm{mg}$ protein ${ }^{-1} \cdot 30 \mathrm{~min}^{-1}$, respectively, $n=9$ in each experimental group). Last, the oxidation of $\mathrm{L}$-lactate was also found to be similar in colonocytes from NP and HP animals, averaging, respectively, $3.41 \pm 0.87$ and $4.44 \pm 1.87$ $\mathrm{nmol} \cdot \mathrm{mg}$ protein ${ }^{-1} \cdot 30 \mathrm{~min}^{-1}(n=3$ in each experimental group).

As indicated in Fig. $4 B$, the mRNA levels of the two monocarboxylic acid transporters $M c t 1$ and Smctl, as well as that of Cd147 (CD147 involved in the apical expression of MCT1 participating in the transport of monocarboxylic acids in colonic epithelial cells), were not significantly different between NP and HP groups. As shown in Fig. $4 C$, with the use of Western blot analysis of cell membrane proteins recovered from colonocytes isolated after NP and HP diet consumption, the amounts of MCT1 and SMCT1 were similar in both groups of animals. Last, by visualizing MCT1 and SMCT1 using immunofluorescence technique, our results indicate similar immunolocalization of both monocarboxylic acid transporters in NP and HP colonocytes (Fig. 4D).

\section{DISCUSSION}

The results obtained in the present study clearly indicate that rats, after the consumption of the HP diet compared with the NP diet, were characterized in the large intestine by an increase in the mass of its luminal content, a shift in microbiota composition, and marked changes in the amount of organic acids, particularly in the colon.

Analysis of bacterial biodiversity with PCR-DGGE strongly suggests that the gut microbiota is deeply reshaped following HP diet ingestion. The fluctuations of biodiversity markers (diversity and richness) suggest changes at the species level resulting from adaptation of the microbiota to the new intestinal environment created by the HP diet. The large intestine microbiota of rats submitted to HP diet had to cope with the 
Table 5. Prevalence of bacterial species identified in the cecal and colonic luminal contents by PCR-DGGE analysis and subsequent DNA sequencing

\begin{tabular}{|c|c|c|c|c|c|}
\hline \multirow[b]{2}{*}{ Bacterial Species } & \multirow[b]{2}{*}{ Accession No. } & \multirow[b]{2}{*}{ Identity, \% } & \multicolumn{2}{|c|}{ No. of Positive Cases/Total Cases (\%) } & \multirow[b]{2}{*}{$P$ Value } \\
\hline & & & NP & HP & \\
\hline \multicolumn{6}{|l|}{ Cecal luminal contents } \\
\hline Actinobacteium sp. & HQ675413 & 98 & $4 / 8(50)$ & $7 / 8(87)$ & 0.282 \\
\hline Alistipes massiliensis & JF824799 & 95 & $3 / 8(37)$ & $0 / 8(0)$ & 0.100 \\
\hline Bacteroides bacterium & GU957728 & 97 & $0 / 8(0)$ & $4 / 8(50)$ & 0.076 \\
\hline B. chinchilla & AB547637 & 94 & $4 / 8(50)$ & $8 / 8(100)$ & 0.076 \\
\hline B. dorei & JF 298878 & 98 & $3 / 8(37)$ & $8 / 8(100)$ & $0.025^{*}$ \\
\hline B. sartorii & AB572597 & 95 & $4 / 8(50)$ & $1 / 8(12)$ & 0.282 \\
\hline B. uniformis & JF298891 & 97 & $2 / 8(25)$ & $4 / 8(50)$ & 0.363 \\
\hline B. vulgatus & EFG22256 & 99 & $0 / 8(0)$ & $7 / 8(87)$ & $0.001 *$ \\
\hline Blautia luti & AJ133124 & 99 & $4 / 8(50)$ & $4 / 8(50)$ & 1.000 \\
\hline Clostridium sp. & AB610549 & 96 & $4 / 8(50)$ & $0 / 8(0)$ & $0.025 *$ \\
\hline Escherichia coli & JQ219679 & 100 & $8 / 8(100)$ & $3 / 8(37)$ & $0.025^{*}$ \\
\hline Fusobacterium sp. & AF342858 & 99 & $0 / 8(0)$ & $6 / 8(75)$ & $0.006^{*}$ \\
\hline Prevotella sp. & DQ273884 & 98 & $7 / 8(87)$ & $5 / 8(62)$ & 0.569 \\
\hline Rhodospirillum sp. & HM998908 & 91 & $0 / 8(0)$ & $4 / 8(50)$ & 0.076 \\
\hline Ruminococcus sp. & DQ882650 & 98 & $2 / 8(25)$ & $0 / 8(0)$ & 0.466 \\
\hline Verrumicrobia bacterium & JN65682 & 93 & $1 / 8(12)$ & $4 / 8(50)$ & 0.282 \\
\hline \multicolumn{6}{|l|}{ Colonic luminal contents } \\
\hline Actinobacterium sp. & HQ675413 & 98 & $7 / 8(87)$ & $8 / 8(100)$ & 0.335 \\
\hline Bacteroides bacterium & GU957728 & 96 & $0 / 8(0)$ & $4 / 8(50)$ & 0.076 \\
\hline B. dorei & EU722737 & 92 & $5 / 8(62)$ & $0 / 8(0)$ & $0.025 *$ \\
\hline B. fibrisolvas & AJ222769 & 97 & $3 / 8(37)$ & $0 / 8(0)$ & 0.100 \\
\hline B. sartorii & AB572597 & 95 & $6 / 8(75)$ & $5 / 8(62)$ & 0.641 \\
\hline B. vulgatus & DQ100446 & 96 & $3 / 8(37)$ & $2 / 8(25)$ & 0.641 \\
\hline Clostridium sp. & FJ625862.1 & 93 & $5 / 8(62)$ & $0 / 8(0)$ & $0.025^{*}$ \\
\hline Enterococcus sp. & AY683831 & 95 & $1 / 8(12)$ & $5 / 8(62)$ & 0.118 \\
\hline Fusobacterium sp. & AF342858 & 98 & $7 / 8(87)$ & $2 / 8(25)$ & $0.040 *$ \\
\hline Lachnospiraceae & AB186803 & 91 & $2 / 8(25)$ & $0 / 8(0)$ & 0.466 \\
\hline Ruminococcus bromii & DQ882649 & 94 & $5 / 8(62)$ & $2 / 8(25)$ & 0.314 \\
\hline
\end{tabular}

PCR-denaturing gradient gel electrophoresis (DGGE) of DNA from the luminal contents recovered from rats after NP/HP feeding for 15 days, using the universal primers HAD-F and HAD-R. *Statistically significant difference.

increased proportion of protein while ensuring the energetic stability of the ecosystem. For instance, HP diet did not influence $B$. fragilis group gene copy number; nevertheless, it increased the prevalence of $B$. vulgatus and $B$. dorei in cecum. $B$. vulgatus is one of the most proteolytic species among the $B$. fragilis group, and it is also known that Bacteroides are one of the gut colonizers that obtains the energy from amino acid fermentation contributing to SCFA generation (30). Recently the Bacteroides enterotype has also been associated with increased intake of dietary protein in humans (75). In both segments of the large intestine, gene copy numbers of $C$. coccoides group, $C$. leptum group, and $F$. prausnitzii (a major member of the C. leptum group) were significantly decreased. The HP diet did not change the other bacterial groups analyzed, but, in colon, the gene copy numbers of total bacteria were slightly but significantly decreased under the HP diet even if the difference measured is close to the variation window of real-time PCR. The changes in clostridia are important since these clusters account for $>90 \%$ of Firmicutes, which is one of the two main phyla colonizing the human gut (21). Some butyrate-producing bacteria are known to belong to the clostridial cluster XIVa, C. coccoides group (4), and F. prausnitzii is also considered as a butyrate-producing bacteria (43). The reduction of these bacterial group numbers in response to low-carbohydrate diets has also been related to reduction in SCFA generation in humans. More recent studies of the fecal microbiota of human vegetarian and omnivores have also reported that the butyryl-CoA-transferase gene, which is asso- ciated with microbial butyrate production, highly correlated with Clostridium cluster XIVa and Roseburia-E. rectale abundance and to a lesser extent with $C$. leptum and $F$. prausnitzii abundance and with crude fiber intake (37). The fact that, in the present study, these bacteria were decreased after HP diet consumption at the expense of carbohydrates is coherent with previous studies. However, the understanding of the specific microbial groups involved in protein metabolism and their relation to SCFA generation in the large intestine is rather limited, and other taxa and genes may be switched on to take over the role that seems to be played by members of clostridial cluster XIVa under a high-carbohydrate diet in the context of a HP diet. Thus, from our results, it appears difficult to assign to what extent the modified luminal content in bacterial metabolites is due to changes in substrate availability compared with changes in microbiota composition.

The enhancement of diversity, richness, and evenness (which was found in cecum) is perceived as beneficial for microbial ecosystems while their reduction (which was found in colon) is considered as unfavorable. In cecum, protein fermentation is believed to be lower than in the colon and particularly compared with the distal colon. However, the fact that we measured a significant amount of BCFA (which derive exclusively from amino acid fermentation) in the cecum indicates that protein fermentation already occurs there.

It is worth noting that the decrease of $C$. leptum and $C$. coccoides groups and $F$. prausnitzii in gut microbiota was previously associated with the active phase of inflammatory 
A
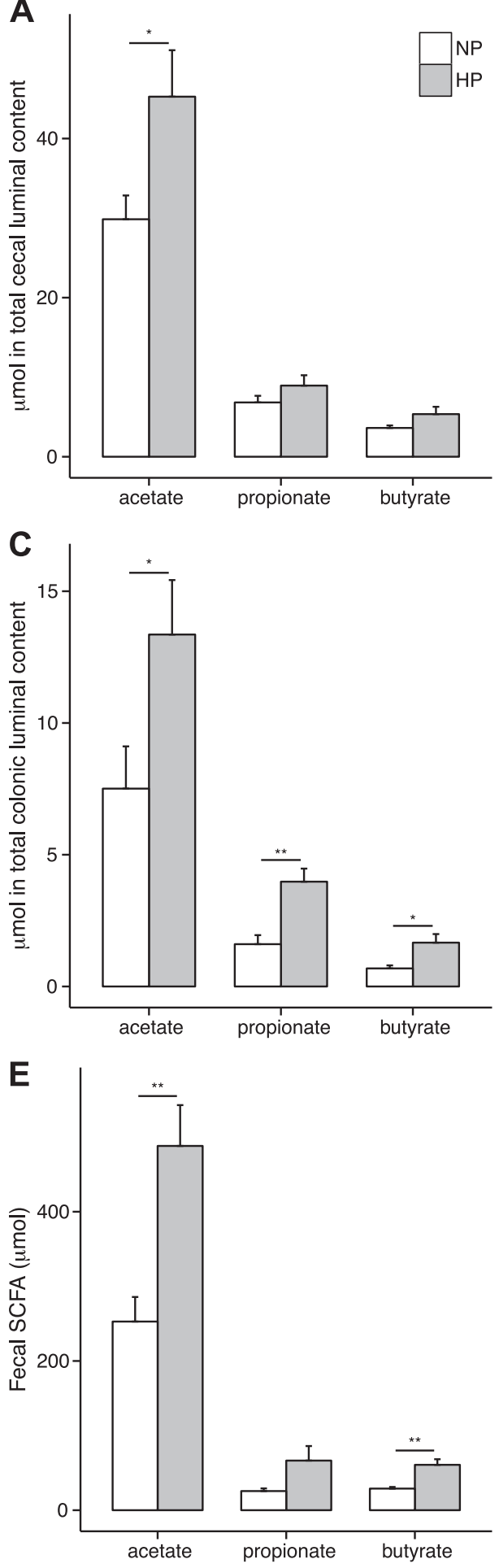

B
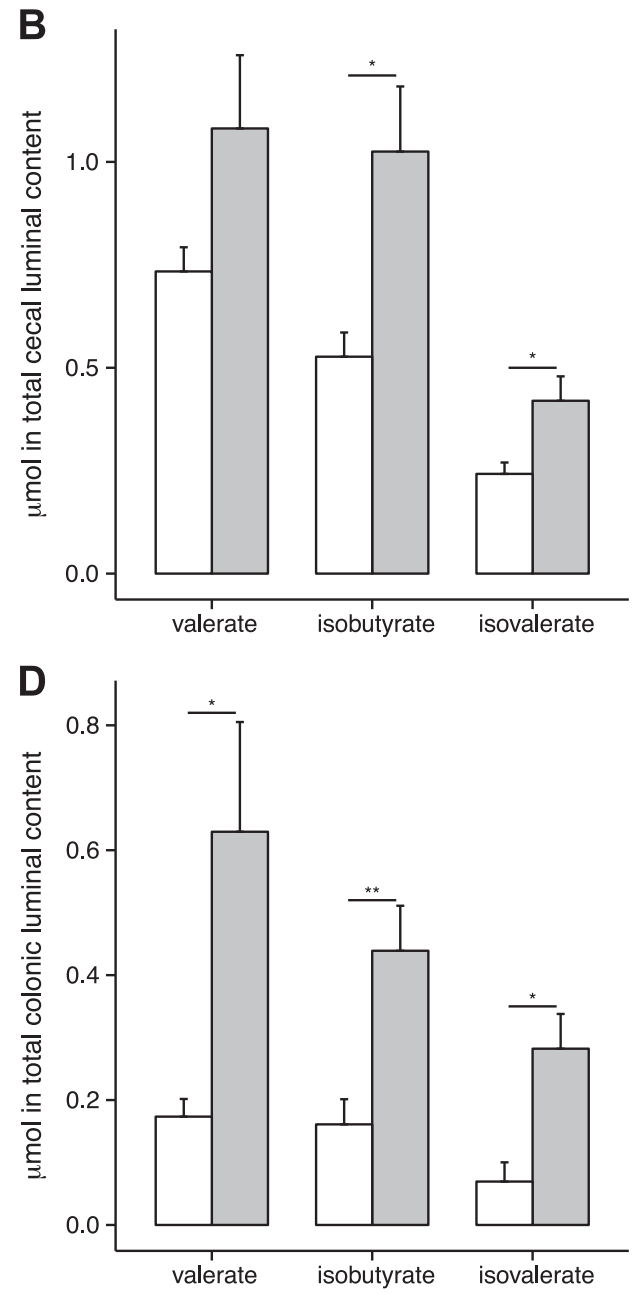

$\mathbf{F}$

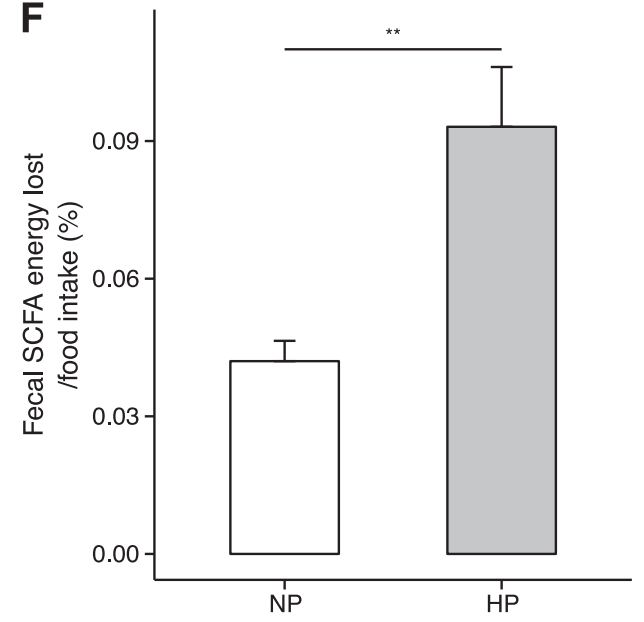

Fig. 3. Total amounts of short-chain fatty acids (SCFA) in the large intestine's luminal contents and in feces recovered from rats after NP/HP feeding for 15 days. $A$ and $B$ : SCFA and branched-chain fatty acids (BCFA) in the cecal luminal contents; $C$ and $D$ : SCFA and BCFA in the colonic luminal contents; $E$ : total fecal SCFA; and $F$ : fecal SCFA expressed as percentages of energy loss. The feces were recovered for the last 3 days before death. To calculate the energy loss as SCFA, total energy in the food ingested is taken as $100 \%$. Results are presented as means \pm SE and were obtained from 8 animals in each group, $* P<0.05$ and $* * P<0.01$. bowel diseases (67). In addition, anti-inflammatory effects of $F$. prausnitzii in the trinitrobenzene sulfonate-induced colitis model were also reported (66). Next, it can be hypothesized that HP diet ingestion may create an unfavorable luminal condition in terms of microbiota composition in the large intestine in the case of subsequent inflammatory episodes. Further work, out of the scope of the present study, is necessary to document this new working hypothesis.
HP rats showed a marked increase of the total content of almost all the measured monocarboxylic acids in the colon luminal contents. In cecal content, the situation was not vastly different but less marked.

These results are compatible with the view that, despite lower food intake in the HP group, more proteins and then amino acid substrates were available to the microbiota in the large intestine for the synthesis of SCFA (from alanine, aspar- 
Table 6. Total amounts of organic acids and ethanol in the total cecal and colonic luminal contents recovered from rats after NP/HP feeding for 15 days

\begin{tabular}{|c|c|c|c|c|c|}
\hline \multirow[b]{2}{*}{$\mu \mathrm{mol}$ in Total Luminal Contents } & \multicolumn{2}{|c|}{ NP } & \multicolumn{2}{|c|}{ HP } & \multirow[b]{2}{*}{$P$ Value } \\
\hline & Mean & SE & Mean & SE & \\
\hline \multicolumn{6}{|l|}{ Cecal luminal contents } \\
\hline L-Lactate & 0.214 & 0.036 & 0.390 & 0.088 & 0.095 \\
\hline D-Lactate & 0.098 & 0.014 & 0.145 & 0.043 & 0.325 \\
\hline Succinate & 3.452 & 0.585 & 7.505 & 0.845 & $0.002 *$ \\
\hline Formate & 0.565 & 0.027 & 0.947 & 0.114 & $0.015^{*}$ \\
\hline Ethanol & 27.590 & 8.388 & 23.352 & 11.821 & 0.775 \\
\hline \multicolumn{6}{|l|}{ Colonic luminal contents } \\
\hline L-Lactate & 0.053 & 0.006 & 0.210 & 0.029 & $<0.001 *$ \\
\hline D-Lactate & 0.004 & 0.002 & 0.008 & 0.002 & $0.040 *$ \\
\hline Succinate & 0.905 & 0.625 & 7.064 & 1.066 & $<0.001 *$ \\
\hline Formate & 0.064 & 0.013 & 0.177 & 0.044 & 0.052 \\
\hline Ethanol & 0.796 & 0.142 & 1.756 & 0.340 & $0.031 *$ \\
\hline
\end{tabular}

Results were obtained from 6-8 animals in each group. *Statistically significant difference.

tate, glutamate, glycine, lysine, threonine), BCFA (from isoleucine, leucine, valine), and other organic acids (from deamination and fermentation of amino acids) $(5,22,44,45)$. This will correspond to a loss of amino acids for the host since the colonic epithelium (except in the neonatal period) cannot absorb a significant amount of amino acids. Among the 10 monocarboxylic acids that were markedly increased in colonic content, some of them (butyrate, acetate, propionate, and L-lactate) have been shown to represent important luminal oxidative substrates providing energy in the form of ATP for the colonic epithelial cells. In the case of succinate, this metabolite has been shown to be transported within the colonic mucosa (74) and to increase oxygen consumption in colonocytes (31). Because the large intestine epithelial layer is renewed within a few days (with important corresponding anabolic ATP-consuming pathways) (54), together with consumption of ATP by colonocytes through the membrane-bound ATPase involved in colonic electrolyte transport (7), ATP has to be synthesized at a rate matching its cellular utilization to maintain a constant ATP cell content, a necessary condition to maintain the viability of epithelial cells (41). The other monocarboxylic acids (valerate, isobutyrate, isovalerate, formate, and D-lactate), which have not yet been tested for their capacity to be oxidized in colonocyte, are present in much lower amounts than SCFA and succinate. Interestingly, the amount of ethanol in colonic content recovered from HP animals was markedly increased compared with NP animals. It remains, however, to be determined if ethanol is absorbed through the colonic epithelium with or without metabolism during its transfer from the lumen to the bloodstream. Ethanol, succinate, formate, and lactate, as metabolic intermediates in microbiota metabolism, usually do not accumulate to any substantial extent in the large intestine content. However, the production of these latter compounds can be increased under specific circumstances $(33,45)$.

Microbiota-derived energy substrates, which are absorbed in the process of transfer from the intestinal lumen to the portal vein blood, are available first for the liver and then, for some of them, for other peripheral tissues. In other words, transport from the lumen inside the colonocytes and further metabolism in these cells will primarily determine the amount of energy substrates available for liver and peripheral tissues in host. From this point of view, our results showing that the expression of the monocarboxylic acid transporters MCT1 and SMCT1 is not significantly modified after HP diet consumption represent strong evidence indicating similar capacities for luminal transport of energy substrates originating from the microbiota by the colonic epithelium. More evidence in favor of similar transport of monocarboxylic acids in colonocytes from HP and NP animals originates from the calculation of SCFA concentrations in the colonic lumen. Indeed, when we calculate acetate, propionate, and butyrate concentrations, they are not

Table 7. SCFA concentrations in the cecal and colonic luminal contents recovered from rats after NP/HP feeding for 15 days

\begin{tabular}{|c|c|c|c|c|c|}
\hline \multirow[b]{2}{*}{$\mu \mathrm{mol} / \mathrm{g}$ of Wet Luminal Contents } & \multicolumn{2}{|c|}{ NP } & \multicolumn{2}{|c|}{$\mathrm{HP}$} & \multirow[b]{2}{*}{$P$ Value } \\
\hline & Mean & SE & Mean & SE & \\
\hline \multicolumn{6}{|l|}{ Cecal luminal contents } \\
\hline Acetate & 15.186 & 1.046 & 16.848 & 1.636 & 0.409 \\
\hline Propionate & 3.446 & 0.292 & 3.282 & 0.331 & 0.716 \\
\hline Butyrate & 1.886 & 0.161 & 1.986 & 0.288 & 0.768 \\
\hline Valerate & 0.378 & 0.022 & 0.399 & 0.058 & 0.733 \\
\hline \multicolumn{6}{|l|}{ Colonic luminal contents } \\
\hline Acetate & 9.714 & 2.610 & 10.413 & 1.430 & 0.819 \\
\hline Propionate & 2.065 & 0.554 & 3.291 & 0.573 & 0.147 \\
\hline Butyrate & 0.905 & 0.205 & 1.358 & 0.274 & 0.208 \\
\hline Valerate & 0.168 & 0.055 & 0.436 & 0.130 & 0.090 \\
\hline
\end{tabular}

Results were obtained from 8 animals in each group. 
A

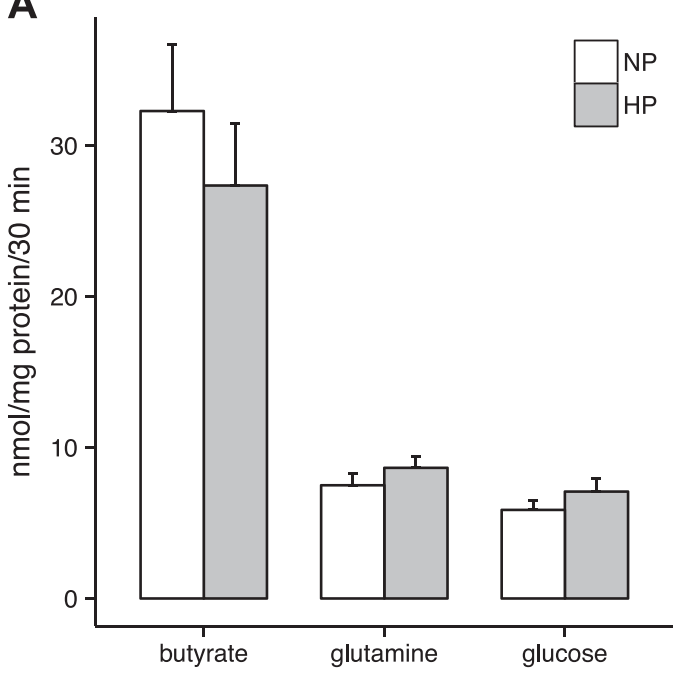

B

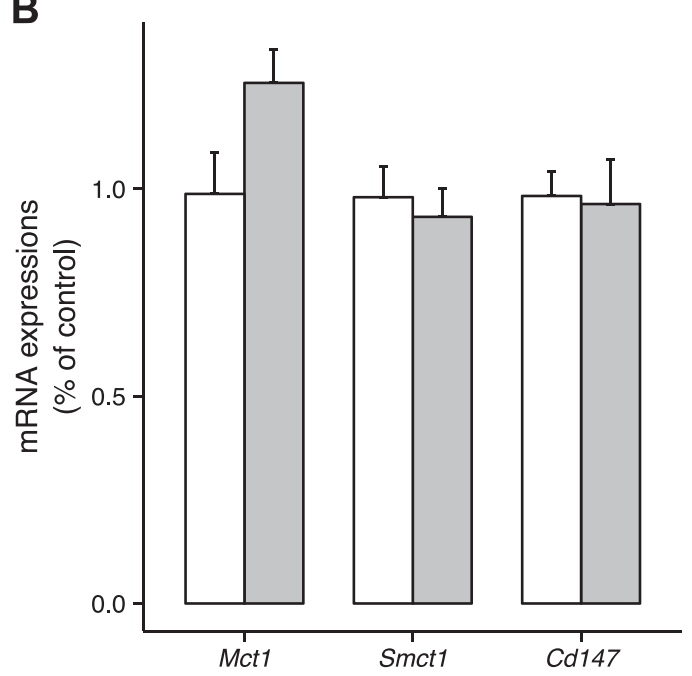

C

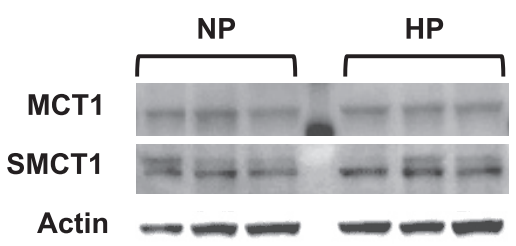

D

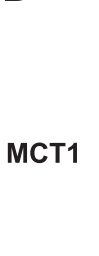

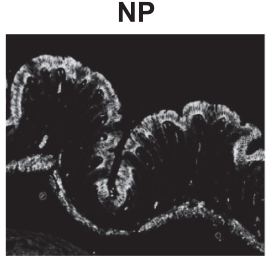

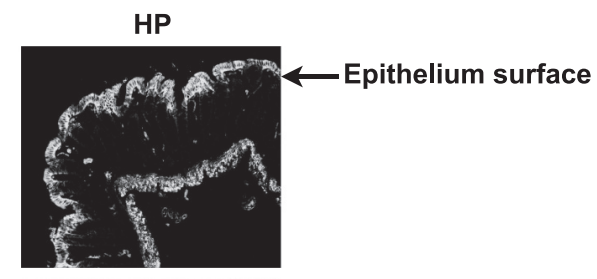

SMCT1
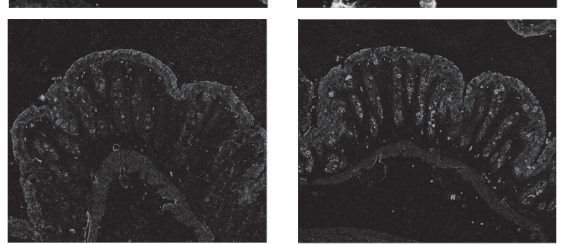

Fig. 4. Oxidation of energy substrates and expression of monocarboxylate transporters in isolated colonocytes and colonic sections from rats after NP/HP feeding for 15 days. A: oxidation of butyrate $(2 \mathrm{mM})$, L-glutamine $(1 \mathrm{mM})$, and D-glucose $(5 \mathrm{mM})$ by the isolated colonocytes recovered from rats after NP/HP feeding for 15 days. Results are expressed as means \pm SE and were obtained from 8-9 animals in each group. B: gene expression of monocarboxylate transporter 1 (Mct1), sodium monocarboxylate transporter 1 (Smct1), and Cd147 in isolated colonocytes. The mRNA expression was determined by real-time PCR, and the results were normalized with Rpl13a mRNA and are obtained from 5-6 animals in each group; $C$ : Western blot analysis of membrane MCT1 and SMCT1 in isolated colonocytes. Images are representative immunoblots of MCT1, SMCT1, and $\beta$-actin from 5 animals in each group; $D$ : Immunofluorescence staining of MCT1 and SMCT1 in colonic sections. The immunoblots are representative of results obtained from 5 animals in each group.

significantly different in the colonic lumen of NP and HP animals.

Incidentally, the increased weight of the colonic luminal contents can be largely explained by increased water retention after HP diet consumption (42). From these results, and the low-affinity $K_{\mathrm{m}}$ value of butyrate transport in colonic epithelial cells (40), we can predict that transport of SCFA from the lumen to the colonocyte will be similar between HP and NP animals. In further support of this proposition, we found that colonocytes from HP and NP animals oxidized butyrate and lactate to the same extent. Because we found that, in colonocytes isolated from HP and NP animals, the oxidation of the substrates L-glutamine and D-glucose (originating from the arterial blood) are similar (as well as the conversion of D-glucose to lactate), our results indicate similar energy metabolism capacity of the colonocytes whatever the diet consumed.

The present results strongly suggest that the increase of the bulk of the colonic content induced by the protein-rich diet allows the concentrations of luminal energy substrates to re- main constant. Such maintenance, in the condition of modified luminal environment, is presumably important taking into account that, as suggested by previous studies $(9,63)$, the profile of luminal energy substrates available to colonic epithelial cells and metabolic characteristics of these cells play a major role in the control of processes such as cell proliferation/ differentiation, which are central for the epithelium renewal and its homeostasis. Because the capacity for SCFA transport and metabolism by the colonic epithelium after HP diet consumption remained unchanged, we predicted that a part of these luminal energy substrates will be lost by the host (46). This was exactly what we observed with a more than twofold increase of the amount recovered in the feces of HP animals compared with NP animals. However, in HP animals, the part of energy lost in feces as SCFA remains quite modest, averaging $\sim 0.1 \%$ of the energy ingested. A beneficial counterpart to amino acid and energy wasting is likely related to the physiology of the colonic epithelium. Indeed, among SCFA, butyrate plays a unique role by serving both as an energy substrate in colonocytes and as a regulator for intracellular 
gene targets, including those involved in colonic epithelial cell proliferation and migration $(1,73)$.

Thus, the same butyrate transport and oxidation in mitochondria of colonocytes recovered from HP and NP animals likely represents a way to maintain butyrate intracellular concentration within a narrow range compatible with its action upon its targets, including nuclear ones related to the epigenetic regulation of gene expression $(15,71)$. Because the expression of the MCT1 transporter in the colonocyte brushborder membrane is sensitive to the butyrate concentration (10, 16), the maintenance of the luminal concentration of butyrate despite increased protein consumption and butyrate production by the microbiota would thus allow maintaining metabolic homeostasis in the colonic epithelium. In conclusion, the data presented in this study are compatible with the view that an increased bulk in the large intestine contents following HP diet ingestion allows some kind of homeostasis regarding bacterial metabolites produced by the microbiota in a context of modified composition and increased substrate availability. Particularly, the present study indicates that, despite a marked increase of the amount of butyrate in the colonic luminal contents, a rather constant concentration is associated with unchanged capacity of colonic epithelial cells for its transport and metabolism. Because of the complexity of metabolic reactions and interconversions involving microbiota and its environment, further studies particularly involving high-throughput analysis are necessary to better explain the taxonomic and functional differences resulting from the HP diet and their long-term consequences on host-microbiota interactions.

\section{ACKNOWLEDGMENTS}

We acknowledge Patrick Even for helpful discussion and Corine Delteil for technical help.

\section{GRANTS}

This work was supported by INRA, AgroParisTech, and CSIC. J.-M. Blouin received a postdoctoral grant from the Region Ile-de-France (DIM/ Astrea program).

\section{DISCLOSURES}

No conflicts of interest, financial or otherwise, are declared by the authors.

\section{AUTHOR CONTRIBUTIONS}

Author contributions: X.L., J.-M.B., A.S., A.L., M.A., S.W., and P.-H.B. performed experiments; X.L. and J.-M.B. analyzed data; X.L., J.-M.B., and A.S. prepared figures; X.L., F.B., and A.-M.D. drafted manuscript; X.L., J.-M.B., A.S., A.L., M.A., S.W., P.-H.B., D.T., Y.S., F.B., and A.-M.D. edited and revised manuscript; X.L., J.-M.B., A.S., A.L., M.A., S.W., P.-H.B., D.T., Y.S., F.B., and A.-M.D. approved final version of manuscript; Y.S., F.B., and A.-M.D. conception and design of research; F.B. and A.-M.D. interpreted results of experiments.

\section{REFERENCES}

1. Andriamihaja M, Chaumontet C, Tome D, Blachier F. Butyrate metabolism in human colon carcinoma cells: implications concerning its growth-inhibitory effect. J Cell Physiol 218: 58-65, 2009.

2. Archer SYJJ, Kim HJ, Ma Q, Mou H, Dasety V, Meng S, Hodin RA. The histone deacetylase inhibitor butyrate down regulates cyclin B1 gene expression via $\mathrm{p} 21 / \mathrm{WAF}-1$-dependent mechanism in human colon cancer cells. Am J Physiol Gastrointest Liver Physiol 289: G696-G703, 2005.

3. Bach Knudsen KE, Serena A, Canibe N, Juntunen KS. New insight into butyrate metabolism. Proc Nutr Soc 62: 81-86, 2003.

4. Barcenilla A, Pryde SE, Martin JC, Duncan SH, Stewart CS, Henderson C, Flint HJ. Phylogenetic relationships of butyrate-producing bacteria from the human gut. Appl Environ Microbiol 66: 1654-1661, 2000.

5. Barker HA. Amino acid degradation by anaerobic bacteria. Аnnu Rev Biochem 50: 23-40, 1981

6. Binder HJ. Role of colonic short-chain fatty acid transport in diarrhea. Annu Rev Physiol 72: 297-313, 2010.

7. Binder HJ, Sangan P, Rajendran VM. Physiological and molecular studies of colonic H+,K+-ATPase. Semin Nephrol 19: 405-414, 1999.

8. Blachier F, Mariotti F, Huneau JF, Tome D. Effects of amino acidderived luminal metabolites on the colonic epithelium and physiopathological consequences. Amino Acids 33: 547-562, 2007.

9. Boren J, Lee WN, Bassilian S, Centelles JJ, Lim S, Ahmed S, Boros LG, Cascante M. The stable isotope-based dynamic metabolic profile of butyrate-induced HT29 cell differentiation. J Biol Chem 278: 2839528402, 2003.

10. Borthakur A, Saksena S, Gill RK, Alrefai WA, Ramaswamy K, Dudeja PK. Regulation of monocarboxylate transporter 1 (MCT1) promoter by butyrate in human intestinal epithelial cells: involvement of NF-kappaB pathway. J Cell Biochem 103: 1452-1463, 2008.

11. Buyse M, Sitaraman SV, Liu X, Bado A, Merlin D. Luminal leptin enhances CD147/MCT-1-mediated uptake of butyrate in the human intestinal cell line Caco2-BBE. J Biol Chem 277: 28182-28190, 2002.

12. Cano PG, Santacruz A, Trejo FM, Sanz Y. Bifidobacterium CECT 7765 improves metabolic and immunological alterations associated with obesity in high-fat diet fed mice. Obesity (Silver Spring) 21: 2310-2321, 2013.

13. Chacko A, Cummings JH. Nitrogen losses from the human small bowel: obligatory losses and the effect of physical form of food. Gut 29: 809-815, 1988.

14. Chomczynski P, Sacchi N. Single-step method of RNA isolation by acid guanidinium thiocyanate-phenol-chloroform extraction. Anal Biochem 162: $156-159,1987$.

15. Cuff M, Dyer J, Jones M, Shirazi-Beechey S. The human colonic monocarboxylate transporter Isoform 1: its potential importance to colonic tissue homeostasis. Gastroenterology 128: 676-686, 2005.

16. Cuff MA, Lambert DW, Shirazi-Beechey SP. Substrate-induced regulation of the human colonic monocarboxylate transporter, MCT1. $J$ Physiol 539: 361-371, 2002.

17. Cummings JH, Macfarlane GT. The control and consequences of bacterial fermentation in the human colon. J Appl Bacteriol 70: 443-459, 1991.

18. Cummings JH, Pomare EW, Branch WJ, Naylor CP, Macfarlane GT. Short chain fatty acids in human large intestine, portal, hepatic and venous blood. Gut 28: 1221-1227, 1987.

19. Darcy-Vrillon B, Morel MT, Cherbuy C, Bernard F, Posho L, Blachier F, Meslin JC, Duee PH. Metabolic characteristics of pig colonocytes after adaptation to a high fiber diet. J Nutr 123: 234-243, 1993.

20. Donohoe DR, Collins LB, Wali A, Bigler R, Sun W, Bultman SJ. The Warburg effect dictates the mechanism of butyrate-mediated histone acetylation and cell proliferation. Mol Cell 48: 612-626, 2012.

21. Eckburg PB, Bik EM, Bernstein CN, Purdom E, Dethlefsen L, Sargent M, Gill SR, Nelson KE, Relman DA. Diversity of the human intestinal microbial flora. Science 308: 1635-1638, 2005.

22. Elsden SR, Hilton MG. Volatile acid production from threonine, valine, leucine and isoleucine by clostridia. Arch Microbiol 117: 165-172, 1978.

23. Evenepoel P, Claus D, Geypens B, Hiele M, Geboes K, Rutgeerts P, Ghoos Y. Amount and fate of egg protein escaping assimilation in the small intestine of humans. Am J Physiol Gastrointest Liver Physiol 277: G935-G943, 1999.

24. Fromentin G, Darcel N, Chaumontet C, Marsset-Baglieri A, Nadkarni N, Tome D. Peripheral and central mechanisms involved in the control of food intake by dietary amino acids and proteins. Nutr Res Rev 25: 29-39, 2012.

25. Gaudichon C, Bos C, Morens C, Petzke KJ, Mariotti F, Everwand J, Benamouzig R, Dare S, Tome D, Metges CC. Ileal losses of nitrogen and amino acids in humans and their importance to the assessment of amino acid requirements. Gastroenterology 123: 50-59, 2002.

26. Genell S, Gustafsson BE, Ohlsson K. Quantitation of active pancreatic endopeptidases in the intestinal contents of germfree and conventional rats. Scand J Gastroenterol 11: 757-762, 1976.

27. Gibson GR, Roberfroid MB. Dietary modulation of the human colonic microbiota: introducing the concept of prebiotics. J Nutr 125: 1401-1412, 1995. 
28. Gibson GR, Willems A, Reading S, Collins MD. Fermentation of non-digestible oligosaccharides by human colonic bacteria. Proc Nutr Soc 55: 899-912, 1996.

29. Gibson JA, Sladen GE, Dawson AM. Protein absorption and ammonia production: the effects of dietary protein and removal of the colon. $\mathrm{Br} \mathrm{J}$ Nutr 35: 61-65, 1976.

30. Gill SR, Pop M, Deboy RT, Eckburg PB, Turnbaugh PJ, Samuel BS, Gordon JI, Relman DA, Fraser-Liggett CM, Nelson KE. Metagenomic analysis of the human distal gut microbiome. Science 312: 1355-1359, 2006.

31. Goubern M, Andriamihaja M, Nubel T, Blachier F, Bouillaud F. Sulfide, the first inorganic substrate for human cells. FASEB $J$ 21: 1699-1706, 2007.

32. Gustafsson BE. The physiological importance of the colonic microflora. Scand J Gastroenterol Suppl 77: 117-131, 1982.

33. He T, Priebe MG, Harmsen HJ, Stellaard F, Sun X, Welling GW, Vonk RJ. Colonic fermentation may play a role in lactose intolerance in humans. J Nutr 136: 58-63, 2006.

34. Hinnebusch BF, Meng S, Wu JT, Archer SY, Hodin RA. The effects of short-chain fatty acids on human colon cancer cell phenotype are associated with histone hyperacetylation. J Nutr 132: 1012-1017, 2002.

35. Hooda S, Boler BM, Serao MC, Brulc JM, Staeger MA, Boileau TW, Dowd SE, Fahey GC Jr, Swanson KS. 454 pyrosequencing reveals a shift in fecal microbiota of healthy adult men consuming polydextrose or soluble corn fiber. J Nutr 142: 1259-1265, 2012.

36. Johnstone AM. Safety and efficacy of high-protein diets for weight loss. Proc Nutr Soc 71: 339-349, 2012.

37. Kabeerdoss J, Devi RS, Mary RR, Ramakrishna BS. Faecal microbiota composition in vegetarians: comparison with omnivores in a cohort of young women in southern India. Br J Nutr 108: 953-957, 2012.

38. Klenk J, Nagel G, Ulmer H, Strasak A, Concin H, Diem G, Rapp K. Body mass index and mortality: results of a cohort of 184,697 adults in Austria. Eur J Epidemiol 24: 83-91, 2009.

39. Kristensen NB, Pierzynowski SG, Danfaer A. Net portal appearance of volatile fatty acids in sheep intraruminally infused with mixtures of acetate, propionate, isobutyrate, butyrate, and valerate. J Anim Sci 78: $1372-1379,2000$

40. Lecona E, Olmo N, Turnay J, Santiago-Gomez A, Lopez de Silanes I, Gorospe M, Lizarbe MA. Kinetic analysis of butyrate transport in human colon adenocarcinoma cells reveals two different carrier-mediated mechanisms. Biochem J 409: 311-320, 2008.

41. Leschelle X, Goubern M, Andriamihaja M, Blottiere HM, Couplan E, Gonzalez-Barroso MD, Petit C, Pagniez A, Chaumontet C, Mignotte B, Bouillaud F, Blachier F. Adaptative metabolic response of human colonic epithelial cells to the adverse effects of the luminal compound sulfide. Biochim Biophys Acta 1725: 201-212, 2005.

42. Livesey G, Elia M. Estimation of energy expenditure, net carbohydrate utilization, and net fat oxidation and synthesis by indirect calorimetry: evaluation of errors with special reference to the detailed composition of fuels. Am J Clin Nutr 47: 608-628, 1988.

43. Louis P, Flint HJ. Diversity, metabolism and microbial ecology of butyrate-producing bacteria from the human large intestine. FEMS Microbiol Lett 294: 1-8, 2009.

44. Macfarlane GT. Microbiological Aspects of the Production of ShortChain Fatty Acids in the Large Bowel. Cambridge, UK: Cambridge Univ Press, 1995, p. 87-105.

45. Macfarlane GT, Macfarlane S. Bacteria, colonic fermentation, and gastrointestinal health. J AOAC Int 95: 50-60, 2012.

46. Macfarlane S, Macfarlane GT. Regulation of short-chain fatty acid production. Proc Nutr Soc 62: 67-72, 2003.

47. Malinen E, Rinttila T, Kajander K, Matto J, Kassinen A, Krogius L, Saarela M, Korpela R, Palva A. Analysis of the fecal microbiota of irritable bowel syndrome patients and healthy controls with real-time PCR. Am J Gastroenterol 100: 373-382, 2005.

48. Martinez-Medina M, Denizot J, Dreux N, Robin F, Billard E, Bonnet R, Darfeuille-Michaud A, Barnich N. Western diet induces dysbiosis with increased $\mathrm{E}$ coli in CEABAC10 mice, alters host barrier function favouring AIEC colonisation. Gut 63: 116-124, 2014.

49. Matsuki T, Watanabe K, Fujimoto J, Miyamoto Y, Takada T, Matsumoto K, Oyaizu H, Tanaka R. Development of 16S rRNA-genetargeted group-specific primers for the detection and identification of predominant bacteria in human feces. Appl Environ Microbiol 68: 54455451, 2002.
50. Matsuki T, Watanabe K, Fujimoto J, Takada T, Tanaka R. Use of $16 \mathrm{~S}$ rRNA gene-targeted group-specific primers for real-time PCR analysis of predominant bacteria in human feces. Appl Environ Microbiol 70: 7220 $7228,2004$.

51. Miner-Williams W, Deglaire A, Benamouzig R, Fuller MF, Tome D, Moughan PJ. Endogenous proteins in terminal ileal digesta of adult subjects fed a casein-based diet. Am J Clin Nutr 96: 508-515, 2012.

52. Mouille B, Robert V, Blachier F. Adaptative increase of ornithine production and decrease of ammonia metabolism in rat colonocytes after hyperproteic diet ingestion. Am J Physiol Gastrointest Liver Physiol 287: G344-G351, 2004.

53. Nyangale EP, Mottram DS, Gibson GR. Gut microbial activity, implications for health and disease: the potential role of metabolite analysis. $J$ Proteome Res 11: 5573-5585, 2012.

54. Potten CS, Grant HK. The relationship between ionizing radiationinduced apoptosis and stem cells in the small and large intestine. $\mathrm{Br} \mathrm{J}$ Cancer 78: 993-1003, 1998.

55. Rasmussen HS, Holtug K, Mortensen PB. Degradation of amino acids to short-chain fatty acids in humans. An in vitro study. Scand J Gastroenterol 23: 178-182, 1988.

56. Reeves PG, Nielsen FH, Fahey GC Jr. AIN-93 purified diets for laboratory rodents: final report of the American Institute of Nutrition ad hoc writing committee on the reformulation of the AIN-76A rodent diet. J Nutr 123: 1939-1951, 1993.

57. Ritzhaupt A, Wood IS, Ellis A, Hosie KB, Shirazi-Beechey SP. Identification and characterization of a monocarboxylate transporter 513: 719-732, 1998.

58. Roediger WE. Utilization of nutrients by isolated epithelial cells of the rat colon. Gastroenterology 83: 424-429, 1982.

59. Santacruz A, Collado MC, Garcia-Valdes L, Segura MT, MartinLagos JA, Anjos T, Marti-Romero M, Lopez RM, Florido J, Campoy C, Sanz Y. Gut microbiota composition is associated with body weight, weight gain and biochemical parameters in pregnant women. Br J Nutr 104: 83-92, 2010.

60. Sanz Y, Sanchez E, Marzotto M, Calabuig M, Torriani S, Dellaglio F. Differences in faecal bacterial communities in coeliac and healthy children as detected by PCR and denaturing gradient gel electrophoresis. FEMS Immunol Med Microbiol 51: 562-568, 2007.

61. Schwarz J, Tome D, Baars A, Hooiveld GJ, Muller M. Dietary protein affects gene expression and prevents lipid accumulation in the liver in mice. PLoS One 7: e47303, 2012.

62. Siavoshian S, Blottiere HM, Cherbut C, Galmiche JP. Butyrate stimulates cyclin D and p21 and inhibits cyclin-dependent kinase 2 expression in HT-29 colonic epithelial cells. Biochem Biophys Res Commun 232: 169-172, 1997.

63. Singh B, Halestrap AP, Paraskeva C. Butyrate can act as a stimulator of growth or inducer of apoptosis in human colonic epithelial cell lines depending on the presence of alternative energy sources. Carcinogenesis 18: 1265-1270, 1997.

64. Smiddy FG, Gregory SD, Smith IB, Goligher JC. Faecal loss of fluid, electrolytes, and nitrogen in colitis before and after ileostomy. Lancet 1: 14-19, 1960.

65. Smith JG, Yokoyama WH, German JB. Butyric acid from the diet: actions at the level of gene expression. Crit Rev Food Sci Nutr 38: 259-297, 1998.

66. Sokol H, Pigneur B, Watterlot L, Lakhdari O, Bermudez-Humaran LG, Gratadoux JJ, Blugeon S, Bridonneau C, Furet JP, Corthier G, Grangette C, Vasquez N, Pochart P, Trugnan G, Thomas G, Blottiere HM, Dore J, Marteau P, Seksik P, Langella P. Faecalibacterium prausnitzii is an anti-inflammatory commensal bacterium identified by gut microbiota analysis of Crohn disease patients. Proc Natl Acad Sci USA 105: 16731-16736, 2008.

67. Sokol H, Seksik P, Furet JP, Firmesse O, Nion-Larmurier I, Beaugerie L, Cosnes J, Corthier G, Marteau P, Dore J. Low counts of Faecalibacterium prausnitzii in colitis microbiota. Inflamm Bowel Dis 15: 1183-1189, 2009.

68. Tothmeresz B. Comparison of different methods for diversity ordering. $J$ Veg Sci 283-290, 1995.

69. Walker AW, Ince J, Duncan SH, Webster LM, Holtrop G, Ze X, Brown D, Stares MD, Scott P, Bergerat A, Louis P, McIntosh F, Johnstone AM, Lobley GE, Parkhill J, Flint HJ. Dominant and dietresponsive groups of bacteria within the human colonic microbiota. ISME J 5: 220-230, 2011. 
70. Walter J, Tannock GW, Tilsala-Timisjarvi A, Rodtong S, Loach DM, Munro K, Alatossava T. Detection and identification of gastrointestinal Lactobacillus species by using denaturing gradient gel electrophoresis and species-specific PCR primers. Appl Environ Microbiol 66: 297-303, 2000.

71. Wellen KE, Hatzivassiliou G, Sachdeva UM, Bui TV, Cross JR, Thompson CB. ATP-citrate lyase links cellular metabolism to histone acetylation. Science 324: 1076-1080, 2009.

72. Westerterp-Plantenga MS, Nieuwenhuizen A, Tome D, Soenen S, Westerterp KR. Dietary protein, weight loss, and weight maintenance. Аппи Rev Nutr 29: 21-41, 2009.
73. Wilson AJ, Gibson PR. Short-chain fatty acids promote the migration of colonic epithelial cells in vitro. Gastroenterology 113: 487-496, 1997.

74. Wolffram S, Badertscher M, Scharrer E. Carrier-mediated transport is involved in mucosal succinate uptake by rat large intestine. Exp Physiol 79: 215-226, 1994.

75. Wu GD, Chen J, Hoffmann C, Bittinger K, Chen YY, Keilbaugh SA, Bewtra M, Knights D, Walters WA, Knight R, Sinha R, Gilroy E, Gupta K, Baldassano R, Nessel L, Li H, Bushman FD, Lewis JD. Linking long-term dietary patterns with gut microbial enterotypes. Science 334: 105-108, 2011

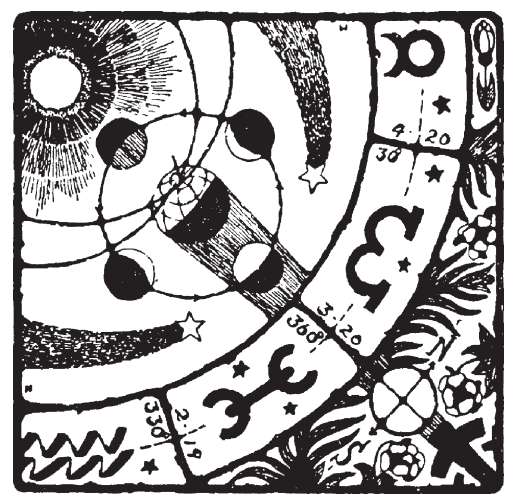

